\title{
PENGARUH PEMBERIAN ALFA MANGOSTIN TERHADAP KADAR GLUKOSA PADA TIKUS YANG DIINDUKSI DIET TINGGI FRUKTOSA
}

\author{
Andreas Putro Ragil Santoso, Devyana Dyah Wulandari \\ Program Studi D-IV Analis Kesehatan, Fakultas Kesehatan, \\ Universitas Nahdlatul Ulama Suarabaya \\ Email: andreasprs87@unusa.ac.id
}

\begin{abstract}
A single alpha mangostin compound obtained from the isolation of Garvinia mangostana Linn fruit peels. Many studies have stated that the compound from alpha mangostin has bioactivities, such as antioxidants, anticancer, anti-diabetic and anti-inflammatory properties. Antidiabetics have and important meaning for diabetics to reduce glucose level in the blood. This study aims to determine whether there is an effect of alpha mangostin on glucose levels in rats induced by fructose diet. The design in this research method is experimental type posttest only control group with 5 treatments, namely negative control, positive control alpha mangostin $50 \mathrm{mg} / \mathrm{kg} \mathrm{BW,100} \mathrm{mg/kg} \mathrm{BW}$ and 150 $\mathrm{mg} / \mathrm{kg} \mathrm{BW}$. With a total sample of 30 obtained from 6 rats on every treatment. Furthermore, the results of the research conducted ANOVA test showed the result showed 0,000 or $p<0,005$ so it could be interpreted that there was an effect of giving alpha mangostin on glucose levels.
\end{abstract}

Keywords: Anti-diabetic, Alpha Mangostin, Glucose Levels

\begin{abstract}
ABSTRAK
Alfa mangostin senyawa tunggal yang didapatkan dari isolasi Kulit buah Garvinia mangostana Linn. Penelitian banyak dilakukan menyebutkan bahwa senyawa dari alfa mangostin memiliki sifat bioktifitas seperti, antioksidan, antikanker, antidiabetes dan antiinflamasi. Antidiabetes memiliki arti penting bagi penderita diabetes untuk mengurangi kadar glukosa didalam darah. Penelitian ini ditujukan untuk mengetahui apakah ada pengaruh pemberian alfa mangostin terhadap kadar glukosa pada tikus yang diinduksi diet fruktosa. Rancangan pada metode penelitian ini adalah eksperimental jenis posttest only kontrol grup dengan 5 perlakukan yaitu kontrol negatif, kontrol positif, alfamangostin $50 \mathrm{mg} / \mathrm{kg} \mathrm{BB}, 100 \mathrm{mg} / \mathrm{kg} \mathrm{BB}$ dan $150 \mathrm{mg} / \mathrm{kg}$ BB. Dengan jumlah sampel sebanyak 30 yang didapat dari 6 tikus setiap perlakuan. Selanjutnya hasil penelitian dilakukan uji anova didapatkan hasil yang menunjukkan 0,000 atau $\mathrm{p}<0,005$ sehingga bisa diartikan bahwa terdapat pengaruh pemberian alfamangostin terhadap kadar glukosa.
\end{abstract}

Kata kunci: Antidiabetes, Alfa Mangostin, Kadar Glukosa

\section{PENDAHULUAN}

Glukosa merupakan hasil metabolisme hormon insulin. Glukosa yang berlebih akan dari karbohidrat yang dapat berfungsi sebagai sumber energi utama yang dikontrol oleh diubah menjadi glikogen yang akan di disimpan didalam hati dan otot sebagai cadangan apabila 
diperlukan oleh tubuh. Peningkatan kadar glukosa didalam darah terjadi akibat toleransi glukpsa terganggu (TGT), Gula Darah Puasa Terganggu (GDPT) serta terjadinya diabetes mellitus ${ }^{1}$. Angka kejadian penyakit Diabetes Mellitus (DM) terjadi peningkatan secara drastis diseluruh dunia. Pada tahun 2030 diperkirakan dapat mengancam sekitar 438 juta orang di seluruh dunia dimana sekitar $70 \%$ kasus merupakan negara-negara dengan penghasilan menengah kebawah ${ }^{2}$. Berdasarkan pusat dan dan informasi kemenkes tahun 2019 pada hari diabetes sedunia diabetes merupakan suatu jenis penyakit krosnis serius yang terjadi karena pancreas tidak menghasilkan cukup akan hormon insulin dimana hormone insulin berperan dalam pengaturan gula di dalam $\operatorname{darah}^{3}$.

Meningkatnya jumlah penyakit DM dapat dikurangi dengan berbagai pengobatan yang sudah banyak diciptakan namun kini perkembangan obat tidak hanya mengarah pada pengobatan melalui kimia namun dilakukan juga pengembangan pengobatan tradisional. Munculnya isu kembali ke alam (back to nature) menimbulkan upaya-upaya baru dalam pengembangan obat tradisional dimana masyarakat kita menyebut obat herbal sebagai obat herbal. Karena obat tradisional banyak ada disekitar lingkungan kita sehingga banyak masyarakat yang mengganggap dan memperlakukan obat-obatan tradisional tanpa kadar khusus karena beranggapan bahwa obat tradisional aman. Meskipun aman bukan berarti obat tradisional tidak memiliki efek samping yang merugikan meskipun efek yang ditimbulkan lebih rendah dibandingkan dengan obat kimia sintesis. Perlu kita ketahui bersama bahwa penggunaan obat itu meskipun obat tradisional. tetap dengan takaran ataupun dosis yang tepat untuk mendapatkan hasil yang optimal. Jadi tidak benar apabila obat tradisional tidak memiliki efek samping, karena sekecil apapun tetap harus diperhatikan efek sampingnya ${ }^{4}$.

\section{Manggis (Garvina mangostana Liin)} merupakan suatu tanaman yang menghasilkan buah yang kaya akan manfaat, selain kayak akan gizi kulit manggis bermanfaat sebagai obat tradisional. pemanfaatan tradisional kulit buah manggis yaitu sebagai pengobatan penyakit disentri, sariawan, gonorea, eksin dan cystitis ${ }^{5}$. Secara umum kulit buah manggis mengandung senyawa metabolit sekunder diantaranya santon, flafonoid dan tannin. Selanjutnya senyawa bioaktif utama yang dimiliki oleh kulit buah manggis yaitu senyawa alfa mangostin, dimana alfa mangosti berupa zat yang berwarna kuning namun tidak larut didalm air melainkan larut didalam methanol, eter, etanol, aseton dan kloroform $^{6}$. Senyawa alfa mangostin yang diisolasi dari ekstrak kulit manggis (Garvina mangostana Linn) kering yang mengandung aktifitas farmakologis diantaranya antioksidan, antiinflamasi, anti jamur, anti bakteri dan anti diabetes $^{7,8}$. 
Antidiabetes merupakan suatu obat yang digunakan untuk mengobati penyakit diabetes mellitus dengan cara mengubah kadar glukosa yang ada di dalam darah sehingga jumlah kadar glukosa didalam darah menurun, namun terjadi pengecualian pada insulin, liraglutide, exenatide fan pramlintide 9 . Antidiabetes digunakan oleh tubuh yang berasal dari bahan alam digunakan sebagai pengganti obat. Dalam penelitian ini alfa mangistin digunakan sebagai antidiabetes, pada penelitian Wulandari, 2012 didapatkan hasil bahwa terdapat penurunan kadar glukosa yang efektif pada pemberian $10 \mathrm{mg} / \mathrm{kg}$ BB dimana penurunan sebesar 37 poin yang bisa dikatakan hamper setara dengan pemberian obat glibenamid.

Alfa mangostin yang di isolasi dari kulit buah manggis dengan metode KLT selanjutnya diperlakukan kepada tikus yang sudah diberikan diet fruktosa. Penelitian ini ditujukan untuk melihat pengaruh alfa mangostin terhadap kadar glukosa didalam darah.

\section{METODE PENELITIAN}

Penelitian ini menggunakan desain penelitian eksperimental dengan jenis posttest only control group. Berdasarkan rumus federer ditemukan sebanyak lebih dari 4 dan peneliti menggunakan 6 setiap perlakuan, dengan rancangan 5 kelompok. Kelompok kontrol positif, kelompok kontrol negatif, kelompok perlakuan yang diberi senyawa alfa mangostin $50 \mathrm{mg} / \mathrm{kg} \mathrm{BB}$, kelompok perlakuan yang diberikan alfa mangostin $100 \mathrm{mg} / \mathrm{kg} \mathrm{BB}$, kelompok perlakuan yang diberikan alfa mangostin $150 \mathrm{mg} / \mathrm{kg}$ BB. Tikus yang digunakan merupakan tikus dengan berat badan sekitar $200 \mathrm{~g}$ dengan jenis tikus yang digunakan adalah tikus Wistar jantan, dengan acuan nilai rujukan < $180 \mathrm{mg} / \mathrm{dl}^{10}$. Varibel dependen merupakan pemberian alfa mangostin 50, 100, $150 \mathrm{mg} / \mathrm{kg}$ BB sedangkan variabel independen merupakan pengukuran glukosa darah. Analisis penelitian menggunakan anova digunakan untuk menghubungkan dua variabel dengan batas magna sebesar 0,05. Bila $\mathrm{p}<0,05$ sehingga dikatakan bahwa terdapat hubungan antar dua variabel, sedangkan $\mathrm{p}>0,05$ maka dikatakan bahwa tidak terdapat hubungan antara kedua variabel.

\section{HASIL DAN PEMBAHASAN}

\section{Hasil Penelitian}

Penelitian dilakukan di laboratorium hewan coba Universitas Nahdlatul Ulama Surabaya, universitas terletak di Jl. Jemursari no 51-57, Wonocolo, Surabaya, Jawa Timur. Universitas Nahdlatul Ulama Surabaya (UNUSA) memiliki 2 kampus yaitu kampus A yang terletak di jalan SMEA sedangkan kampus B terletak di jalan Jemursari, dimana UNUSA sebagian besar merupakan adalah program studi kesehatan sehingga memiliki banyak laboratorium Kesehatan diantaranya Imunologi dan Kimia Klinik, Hewan Coba, Hematologi, Mikrobiologi dll. Sehingga penelitian ini hanya 
dilakukan di lingkungan kampus Universitas Nahdlatul Ulama Surabaya yaitu laboratorium kimia sebagai tempat isolasi senyawa alfa mangostin, laboratorium hewan coba untuk perlakuan hewan coba dan laboratorium imunologi dan kimia klinik untuk pengukuran kadar glukosa.

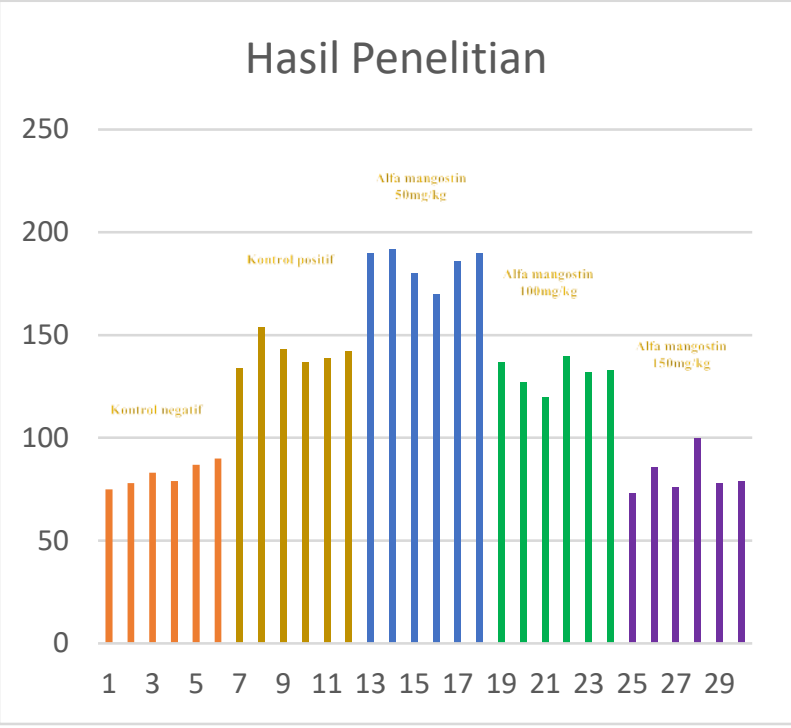

Gambar 1. Hasil penelitian

Berdasarkan pada Gambar 1. menunjukkan hasil pada penelitian bahwa dengan pemberian alfa mangostin penurunan kadar glukosa yaitu pada pemberian $50 \mathrm{mg} / \mathrm{kg}$ BB menghasilkan kadar tertinggi 192 mg/dl dengan maksimal penurunan kadar yaitu 170 $\mathrm{mg} / \mathrm{dl}$ pada pemberian $100 \mathrm{mg} / \mathrm{kg}$ BB manghasilkan kadar tertinggi 140 mg/dl dengan maksimal penurunan hingga $120 \mathrm{mg} / \mathrm{dl}$ sedangkan pada pemberian $150 \mathrm{mg} / \mathrm{kg}$ BB menghasilkan kadar tertinggi pada $100 \mathrm{mg} / \mathrm{dl}$ dengan kadar maksimal penurunan kadar hingga $73 \mathrm{mg} / \mathrm{dl}$.
Tabel 1. Rerata Hasil Kadar Glukosa

\begin{tabular}{ll}
\hline \multicolumn{1}{c}{ Perlakuan } & \multicolumn{1}{c}{ Rerata } \\
\hline Kontrol (-) & $82,00 \mathrm{mg} / \mathrm{dl}$ \\
Kontrol (+) & $141,50 \mathrm{mg} / \mathrm{dl}$ \\
\hline Alfa mangostin $50 \mathrm{mg} / \mathrm{kg} \mathrm{BB}$ & $184,67 \mathrm{mg} / \mathrm{dl}$ \\
Alfa mangostin $100 \mathrm{mg} / \mathrm{kg} \mathrm{BB}$ & $131,50 \mathrm{mg} / \mathrm{dl}$ \\
Alfa mangostin $150 \mathrm{mg} / \mathrm{kg} \mathrm{BB}$ & $82,00 \mathrm{mg} / \mathrm{dl}$ \\
\hline
\end{tabular}

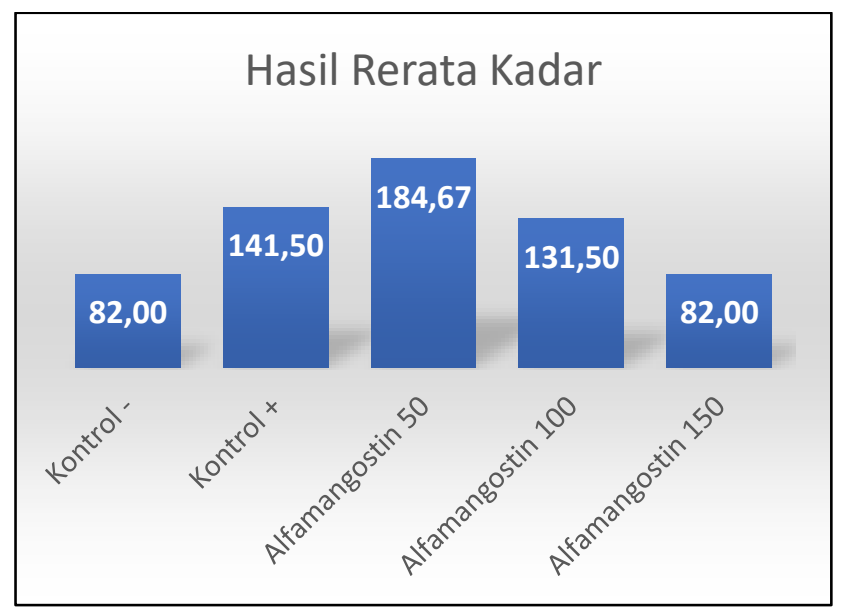

Gambar 2. Hasil Penentuan Kadar

Berdasarkan Tabel 1 dan Gambar 2 menunjukkan bahwa kontrol positif dan kontrol negatif sesuai dengan hasil yang diharapkan dan dari ketiga perlakuan pemberian alfa mangostin yang berfariasi yaitu $50 \mathrm{mg} / \mathrm{kg}$ BB didapatkan rerata kadar glukosa sebesar 186,17 mg/dl, pemberian alfa mangostin sebesar $100 \mathrm{mg} / \mathrm{kg}$ didapatkan rerata kadar glokosa sebasar 131,50 $\mathrm{mg} / \mathrm{dl}$, sedangkan pemberian alfa mangostin sebesar $150 \mathrm{mg} / \mathrm{kg}$ didapatkan rerata kadar glukosa $78,6 \mathrm{mg} / \mathrm{dl}$.

Hal tersebut menunjukkan pemberian alfa mangostin menggambarkan semakin besar pemberian alfa mangostin menunjukkan bahwa penurunan kadar glukosa semakin besar. 
Tabel 2. Hasil Uji Anova

\begin{tabular}{lrrrrc}
\hline & Sum of Squares & \multicolumn{1}{c}{ df } & Mean Square & \multicolumn{1}{c}{ F } & \multicolumn{1}{c}{ Sig } \\
\hline Between Groups & 48277.00 & 4 & 12069.450 & 331.154 & .000 \\
Within Groups & 911.167 & 25 & 36.447 & & \\
Total & 49188.967 & 29 & & & \\
\hline
\end{tabular}

Hasil uji anova menunjukkan dari 5 kelompok perlakuan menunjukkan hasil 0,000 menunjukkan bahwa nilai signifikan $\mathrm{p}<0,05$ yang berarti bahwa terdapat pengaruh pemberian alfa mangostin dengan kadar glukosa. Selanjutnya berdasarkan uji anova tersebut dilakukan uji multiple comparisons "post hoc test" untuk mengetahui hasil pengaruh dan tidak ada pengaruh dari setiap perlakuan kelompok

\section{Pembahasan}

\section{Isolasi alfa mangostin}

Metode pengambilan alfa mangostin dari kulit buah manggis akan sangat mempengaruhi jumlah senyawa yang didapat dari kulit manggis yang diperlakukan. Alfa mangostin pada penelitian ini merupakan senyawa yang didapat berdasarkan hasil ekstraksi kemudian dilakukan pemisahan untuk mendapatkan isolate yang selanjutnya dimoniroring menggunakan metode Kromatografi Lapis Tipis (KLT). Penggunaan KLT dilakukan juga untuk mendapatkan alfa mangostin pada kulit buah manggis ${ }^{11}$. Penelitian oleh Andyana dan Ismed tahun 2017 dalam isolasi alfa mangostin juga menggunakan metode $\mathrm{KLT}^{12}$. Berbeda dengan penelitian lain yang menggunakan kromatografi kolom gravitasi dan kromatografi system radial dengan menganalisa data spektrum UV-Vis, FT-IR, HNMR dan C-NMR untuk medapatkan alfa mangostin dari ekstrak kayu dan kulit akar Garcinia tetranda Pierre ${ }^{13}$. Berdasarkan isolasi uji alfamangostin dari beberapa penelitian untuk mendapatkan alfa mangostin dari kulit manggis menggunakan metode kromatografi lapis tipis sedangkan selain kuliat buah manggis dapat digunakan metode lain.

\section{Pengaruh alfamangostin terhadao kadar glukosa darah}

Uji anova menunjukkan terdapat pengaruh pemberian alfa mangostin terhadap kadar glukosa di dalam darah. Semakin besar alfa mangostin yang diberikan semakin besar penurunan kadar glukosa. Hal ini sama dengan penelitian lainnya yang menunjukkan bahwa alfa mangostin memiliki aktifitas hipoglikemik dan hipopidemik yang dapat memperbaiki pulau Langerhans yang telah rusak, dimana percobaan dilakukan kepada mencit yang diinduksi oleh STZ dengan insukdi sebanyak 2,4,8 mg/kg $\mathrm{BB}^{14}$. Sebuah penelitian yang dilakukan pada mencit dengan dosis $2 \mathrm{mg} / \mathrm{kg}$ BB didapatkan hasil penurunan kadar glukosa darah dan 
meningkatkan diameter pulau Langerhans ${ }^{15}$. Selanjutnya penelitian yang dilakukan oleh Saristiana di tahun 2019, yang dilakukan pada tikus didapatkan bahwa alfa mangostin dapat mengakibatkan penurunan glukosa dan peningkatan kadar insulin ${ }^{16}$. Pada penelitian lainnya, alfa mangostin dapat berfungsi sebagai antidiabetes dan dapat digunakan sebagai pembersihan radikal bebas yang dapat digunakan sebagai konfirmasi efektropik insulin ${ }^{8}$.

Pengaruh alfa mangostin disebabkan disebabkan karena adanya peremajaan pada pancreas melalui sistesis protein, percepatan detoksifikasi, potensiasi dari pertahanna antioksidan dan netrasilasi oleh radikal bebas untuk regenerasi sel beta penghasil insulin ${ }^{2}$. Hasil penelitian dengan ditunjang beberapa penelitian yang lain menunjukkan bahwa pemberian alfa mangostin pada tikus maupun mencit yang diabetic dapat menimbulkan penurunan kadar glukosa didalam darah dikarenakan salah satu sifat alfa mangostin yaitu antidiabetes.

\section{SIMPULAN DAN SARAN}

\section{Simpulan}

Hasil penelitian dilakukan uji statistic anova menunjukkan bahwa hasil signifikasi $\mathrm{p}<$ 0,005 yaitu 0,000 hal tersebut menunjukkan bahwa alfa mangostin memiliki sifat antidiabetes yang berarti bahwa terdapat pengaruh pemberian alfa mangostin terhadap kadar glukosa didalam darah.

\section{Saran}

Penelitian selanjutnya dapat dilakukan uji biokimia darah selain kadar glukosa untuk mengetahui apakah alfa mangostin juga berpengaruh pada biokimia darah yang lain seperti faal hati, faal lipid, faal ginjal. Disamping itu, Alfamangostin dapat di isolasi dari bahan herbal lain.

\section{REFERENSI}

1. Dorland. WA. Kamus Kedokteran Dorland, Edisi-31. Jakarta: EGC. 2012

2. Rawita W, Sukandar EY, Adnyana, Kurniati. Alpha Mangostin and Xanthone Activity on Fasting Blood Glucose, insulin and Langerhans Inslet of Langerhans in Allaxan Induced Diabetic Mice. Pharmacodnosy Journal, 2019. 11(1).

3. Khairani. Hari Diabetes Sedunai Tahun 2018, Infodatin, Kementrian Kesehatan RI. ISSN 2442-7659. 2019.

4. Saepudin E, Rusmana A, Budiono A. Penciptaan Pengetahuan Tentang Tanaman Obat Herbal dan Tanaman Obat Keluarga. Jurnal Kajian Informasi \& Perpustakaan. 2016. 4(1).

5. Putri, IP. Effectivity of Xantone of Mangosteen (Garcina mangostana Linn) Rind As Anticancer, Journal Majority. 2015. 4.

6. Syamsudin, Farida, Widowati, Faizatun Profil Distribusi dan Elinasi Senyawa Alfa Mangostin setelah pemberian oral pada tikus. Jurnal Sains dan Teknologi Farmasi, 2008. 13 (2).

7. Akao, Nagawa, Linuma, Nozawa. Anticancer effect of xanthones from pericarps of mangosteen, international Journal of molecular sciens, 2008. 9. 
8. Kumar PSV, Puranik B, Nandini. Evaluation of Alpha Mangostin Isolated and Purified from the Crude Extract of Garcina mangostna for the Antidiabetic, Anti Inflamatory, Antioxidant Avtivity. International Journal of Pharmacy and Pharmaceutical research (an aofficial publication of Human Journal. 2017. 8(2).

9. Donner, Thomas, Saekar, Anawalt, Boyce, Choursos. Insulin-Pharmacology, Therapeutic Regimens and Principles of Intensive Insulin Therapy, PMID 25905175

10. Amir, Wungouw, Pangemanan. Kadar Glukosa Darah Sewaktu Pada Pasien Diabetes Melitus tipe 2 Di Puskesmas Bahu Kota Manado. Jurnal e-Biomedik (eBM) 2015. 3(1).

11. Wulandari, DD. Isolasi senyawa mangostin dan flavan dan uji bioaktivitas antidiabetes senyawa alfa mangostin dari kulit buah Garcina mangostana Liin. Thesis, Institut Teknologi Sepuluh Nopember. 2012.

12. Andayani R, Ismed F. Analisis alfa mangostin dalam minuman herbal kulit buah manggis (Garcinia mangostana L) dengan metode Kromatografi Lapis TipisDensitometri. Jurnal Sains Farmasi dan Klisnis. 2017. 4 (2), p. 61-66.

13. Ihsany AU, Ersam T. Alfa mangostin dari ekstrak kayu dan kulit akar garcinia tetrada pierre. 2018.

14. Husen SA, Salamun, Ansori ANM, Susilo RJK, Hayaza S, Winarni DRA. The Effect of Alpha mangostine in Glucose level, cholesterol level, and Diameter of the islets of Langerhans of STZ-induced Diabetic Mice. DOI:10.5220/0007547005610566. 2018.

15. Zafira AH. Uji aktifitas antioksidan alfamangostin terhadap kadar glukosa darah dan diameter pulau Langerhans mencit (Mus musculus) Diabetik. Thesis Universitas Airlangga. 2018.
16. Saristiana Y. Aktivitas Akstrak Etanol Kulit Buah Manggis (Garcina mangostana L) dan Alfa Mangostin Terhadap Kadar Insulin Pada Tikus Hiper Glikemi. Thesis. Universitas Setia Budi. 2019. 